\title{
Diketopiperazines Produced by an Aspergillus fumigatus Brazilian Strain
}

\author{
Niege A. J. C. Furtado ${ }^{a}$, Mônica T. Pupo ${ }^{a}$, Ivone Carvalho ${ }^{a}$, \\ Vanessa L. Campo ${ }^{a}$, Marta Cristina T. Duarte ${ }^{b}$ and Jairo K. Bastos ${ }^{*, a}$ \\ ${ }^{a}$ Faculdade de Ciências Farmacêuticas de Ribeirão Preto, Universidade de São Paulo, \\ Avenida do Café s/n, 14040-903 Ribeirão Preto- SP, Brazil \\ ${ }^{b}$ Centro Pluridisciplinar de Pesquisas Químicas, Biológicas e Agrícolas, Universidade de Campinas, \\ Avenida Alexandre Casellato, 999, Vila Betel, 13081-970 Campinas- SP, Brazil
}

Sete dicetopiperazinas, correspondentes aos ciclos (L)-Pro-(L)-Phe, (L)-Pro-Gly, (L)-Pro-(L)Pro, (L)-Pro-(L)-Val, (L)-4-OH-Pro-(L)-Leu, (L)-4-OH-Pro-(L)-Phe e (L)-Pro-(L)-Leu, foram isoladas do caldo da cultura do fungo Aspergillus fumigatus. As estereoquímicas relativas e absolutas foram determinadas, respectivamente, com base nos experimentos de NOESY e através de modificação do método de Marfey em CLAE.

Seven diketopiperazines, corresponding to the cyclos (L)-Pro-(L)-Phe, (L)-Pro-Gly, (L)-Pro(L)-Pro, (L)-Pro-(L)-Val, (L)-4-OH-Pro-(L)-Leu, (L)-4-OH-Pro-(L)-Phe, and (L)-Pro-(L)-Leu, were isolated from the Aspergillus fumigatus fermentation broth. The relative and absolute stereochemistries were determined on the basis of NOESY experiments and by using a modified version of Marfey's method using HPLC, respectively.

Keywords: diketopiperazines, Aspergillus fumigatus, absolute stereochemistry

\section{Introduction}

The search for secondary metabolites from filamentous fungi has led to the discovery of many bioactive compounds. ${ }^{1}$ The structural novelty and diversity of fungal secondary metabolites make them a logical source of new leads for drug discovery and development. Among the 20 most commonly prescribed medications, six are from fungal origin. ${ }^{2}$ The versatility of microbial biosynthesis is conspicuous and the filamentous fungi, as well as the filamentous actinomycetes are the two most prolific groups capable of producing novel secondary metabolites. ${ }^{3}$ In the course of our screening program for antibiotic producers, we selected a Brazilian strain of Aspergillus fumigatus isolated from Pantanal (Mato Grosso do Sul State) soil sample. The interest in A. fumigatus metabolites is due to their broad range of biological activities. ${ }^{4}$ Moreover, Symoens et al..$^{5}$ reported the high genetic polymorphism of A. fumigatus isolates, and according Debeaupuis et al., ${ }^{6}$ the intraspecies variability at the genomic level appears to be very high, reflecting the environmental diversity of this species. Varga and Tóth ${ }^{7}$ described a general overview of the techniques used for the examination of the

* e-mail: jkbastos@fcfrp.usp.br genetic variability of $A$. fumigatus and suggested that recombination played an important role in A. fumigatus populations. Different strains of the same fungus species may produce different compounds using the same medium. ${ }^{8}$ Also, the production of secondary metabolites by fungi may vary with the biotope in which they grow and to which they are adapted. ${ }^{9}$ Fumifungin and synerazol, new antifungal antibiotics, were isolated from the culture broth of $A$. fumigatus. Fumifungin was produced by a strain isolated from a Himalayan soil sample ${ }^{10}$ and synerazol was produced by a strain from Thailand soil sample. ${ }^{11}$ The study of a Brazilian strain of A. fumigatus, aiming to isolate and identify antimicrobial compounds, was undertaken based on the wide variability encountered for this species.

\section{Experimental}

\section{Microorganisms}

Aspergillus fumigatus was isolated from a soil sample collected in Pantanal - MS, Brazil and was identified by the "Fundação Tropical de Pesquisas e Tecnologia André Tosello", Campinas- SP, Brazil. The microorganism is stored as a conidial suspension on silica gel (6-12 mesh, 
grade 40 , desiccant activated) at $4{ }^{\circ} \mathrm{C}$. The Staphylococcus aureus ATCC 25923 and Micrococcus luteus ATCC 9341 strains, used for antimicrobial evaluation, were acquired from the American Type Culture Collection.

\section{Metabolites production}

A two-step culture was performed for secondary metabolites production, consisting of an initial inoculum of a suspension of $4 \times 10^{6}$ conidia $\mathrm{mL}^{-1}$. The fungus was first grown at $40^{\circ} \mathrm{C}$ in five Erlenmeyer flasks containing $200 \mathrm{~mL}$ of seed medium each. ${ }^{12}$ After 24 hours of the incubation on rotary shaker at $120 \mathrm{rpm}$, the resulting mycelia were harvested, rinsed and transferred to a 30 liter Micros I fermenter (New Brunswick Scientific, New Brunswick, NJ, USA), containing 20 liters of fermentation medium (glycerol 1.5\%, sucrose $1.5 \%$, peptone $0.6 \%$, yeast extract $0.15 \%, \mathrm{NaCl} 3.0 \%, \mathrm{KH}_{2} \mathrm{PO}_{4}$ $0.06 \%, \mathrm{MgSO}_{4} \cdot 7 \mathrm{H}_{2} \mathrm{O} 0.5 \%, \mathrm{CuSO}_{4} \cdot 5 \mathrm{H}_{2} \mathrm{O} 0.0001 \%, \mathrm{FeSO}_{4}$. $7 \mathrm{H}_{2} \mathrm{O} 0.0003 \%$ and dimethicone $0.01 \%$ ). The initial $\mathrm{pH}$ value of the medium was set at 6.0 , and the fermentation was carried out at $40{ }^{\circ} \mathrm{C}$ for 144 hours at $200 \mathrm{rpm}$ in the first 24 hours. After that, the stirring speed was increased to 250,280 and $300 \mathrm{rpm}$ at 24,48 and $72 \mathrm{~h}$, respectively. Then, the stirring speed was kept at $300 \mathrm{rpm}$ for additional 72 hours, and aeration rate was maintained at $9 \mathrm{~L} \mathrm{~min}^{-1}$.

\section{Extraction and isolation of compounds}

The culture broth was separated from mycelium by filtration and submitted to three times partition with chloroform. The resulting chloroform fractions were combined and concentrated under vacuum to eliminate the organic solvent. Then, the crude chloroform extract (960 $\mathrm{mg}$ ) was submitted to flash chromatography ${ }^{13}$ over $11 \mathrm{~g}$ of Si gel 60 (230-400 mesh), which was eluted with an isocratic mobile phase of methylene chloride-methanol 49:1. Thinlayer chromatography analysis of the 30 collected fractions allowed to assemble them into 19 fractions. Two active fractions (Fr-18 and Fr-19) were selected from guided bioassay, and further fractionated using an analytical HPLC system. Instrumentations consisted of a Shimadzu (SCL10Avp, Japan) multisolvent delivery system, Shimadzu SPDM10Avp Photodiode Array Detector, and an Intel Celeron computer for analytical system control, data collection and processing. Analytical chromatography of the two active fractions, as well as of the unfermented medium extract was carried out using isocratic gradient (methanol-water 35:65). A CLC-ODS (M) - 4.6 x 250 mm Shimadzu column was used at a flow rate of $1.0 \mathrm{~mL} \mathrm{~min}{ }^{-1}$. The spectral data from the detector were collected over the 200-400 $\mathrm{nm}$ range of the absorption spectrum. The Fr-18 (67.3 mg) yielded $\mathbf{1}$ (2.9 $\mathrm{mg}$ ) and the Fr-19 (41 mg) afforded 2 (3.1 mg), 3 (1.4 mg), 4 $(1.7 \mathrm{mg}), \mathbf{5}(3.2 \mathrm{mg}), \mathbf{6}(2.9 \mathrm{mg})$ and $\mathbf{7}(2.5 \mathrm{mg})$ after being purified by HPLC.

\section{Structure determination of compounds}

The structures of the compounds were determined by spectroscopic techniques, especially by detailed analyses of their ${ }^{1} \mathrm{H}$ and ${ }^{13} \mathrm{C}$ NMR spectra, including 2D NMR techniques (COSY, HMQC and HMBC), as well as mass spectrometry. The relative stereochemistries of the diketopiperazines were determined on the basis of the results of Nuclear Overhauser Effect Spectroscopy (NOESY) experiments. A modified version of Marfey's method ${ }^{14}$ was used to determine the absolute stereochemistries of the individual diketopiperazines amino acids, which were obtained by acid hydrolysis. A small amount $(100 \mathrm{mg})$ of each diketopiperazine was hydrolysed in $6 \mathrm{~mol} \mathrm{~L}^{-1}$ hydrochloric acid at $105^{\circ} \mathrm{C}$, under reflux, for 24 hours. The acid was removed under vacuum, and the acid-free mixture of amino acids was derivatized with the addition of 1-fluoro2,4-dinitrophenyl-5-L-alanine amide (FDAA, Sigma). For that, $100 \mathrm{mg}$ of the mixture of free amino acids were reacted with a solution of $1 \%$ FDAA in acetone $(80 \mu \mathrm{L})$ followed by the addition of $0.5 \mathrm{M} \mathrm{NaHCO}_{3}$ solution $(16 \mu \mathrm{L})$. Then, the resulting mixtures were kept at $40{ }^{\circ} \mathrm{C}$ for one hour. The molar ratio of FDAA to diketopiperazine was set at 2.8:1.0. HPLC was carried out using a reversed-phase column Nucleosil ${ }^{\circledR}$ 100-5 (4.6 mm x $250 \mathrm{~mm}$ ID) packed with $5 \mathrm{~mm}$ spherical silica (Macherey-Nagel). A linear gradient starting with the mixture of triethylamine phosphate buffer $(50 \mathrm{mmol}$ $\mathrm{L}^{-1}, \mathrm{pH}$ 3.5)-MeCN (9:1) and finishing with triethylamine phosphate buffer (50 $\mathrm{mmol} \mathrm{L}^{-1}, \mathrm{pH}$ 3.5)-MeCN (6:4), over 45 minutes (flow rate $1.0 \mathrm{~mL} \mathrm{~min}^{-1}$ ), was used to separate the FDAA derivatives, which were detected by UV at 340 $\mathrm{nm}$. The L-amino acids (Aldrich Co.), used as chromatographic standards, were derivatized as described above, and the diketopiperazine individual amino acids were identified by co-injection with the standards ones.

\section{Bioassay}

The antimicrobial activity of the crude extract was investigated by using both agar diffusion, using Petri dish template system, and bioautography methods. For the first procedure, an aliquot of the extract, free of solvent, was dissolved (5.0 $\mathrm{mg} \mathrm{mL}^{-1}$ ) in 50\% dimethyl sulphoxide (DMSO, $\mathrm{v} / \mathrm{v}$ ) aqueous solution and applied into the template holes on medium surface. Negative controls were run in parallel with DMSO aqueous solution and chloroform. Penicillin G $(0.6075$ $\mathrm{U}, 50 \mu \mathrm{L}$, Sigma) for Micrococcus luteus and penicillin G 
(1.215 U, $50 \mu \mathrm{L}$, Sigma) for Staphylococcus aureus were used as positive controls. The inoculum was prepared by culturing each organism in antibiotic $\mathrm{N}^{\circ} 1$ agar medium (Merck) for 24 hours at $37{ }^{\circ} \mathrm{C}$. The microorganisms were transferred to a $0.9 \% \mathrm{NaCl}$ solution until they reached the turbidity equivalent to $0.5 \mathrm{McFarland}$ standard. Each microorganism suspension $(0.5 \%)$ was poured into antibiotic $\mathrm{N}^{\circ} 1$ agar medium, and distributed over the plates.

For bioautography, the crude extract was dissolved (30 $\mathrm{mg} \mathrm{mL}^{-1}$ ) in ethyl acetate, from which $8 \mu \mathrm{L}$ were applied on silica gel $\mathrm{G} 60 \mathrm{~F}_{254}$ thin layer chromatography plates. The chromatograms were developed in chloroform-methanol (93:7, v/v). After elution, the plates were carefully dried for complete removal of the solvents. Suspensions of microorganisms were prepared in saline solution by comparison with the $0.5 \mathrm{McF}$ arland standard. Afterwards, the suspensions were diluted $(2 \%)$ in antibiotic $\mathrm{N}^{\circ} 1$ agar medium and distributed over the plates. Gentamicin discs were used as positive control. The thin layer chromatography plates were incubated overnight at $37{ }^{\circ} \mathrm{C}$ in a humid chamber. Subsequently, the plates were overlaid with a solution of 2,3,5-triphenyltetrazolium chloride $(0.5 \%, \mathrm{~m} / \mathrm{v})$, and the growth inhibition was observed as clear zones on the chromatograms. ${ }^{15}$ The obtained fractions were evaluated by using bioautography technique, as described above, and the isolated compounds were evaluated in triplicate by microdilution broth method ${ }^{16}$, for which the compounds were solubilized in DMSO and diluted in tryptone soya broth in the range of $15 \mathrm{nmol} \mathrm{L}^{-1}$ to $2.9 \mathrm{mmol} \mathrm{L}^{-1}$. The inoculum was adjusted to each organism to achieve a cell
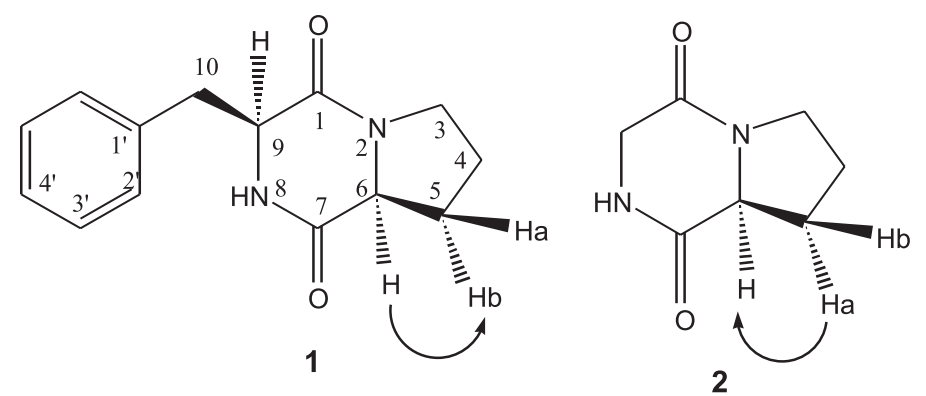<smiles>O=C1[C@@H]2CCCN2C(=O)[C@@H]2CCCN12</smiles>
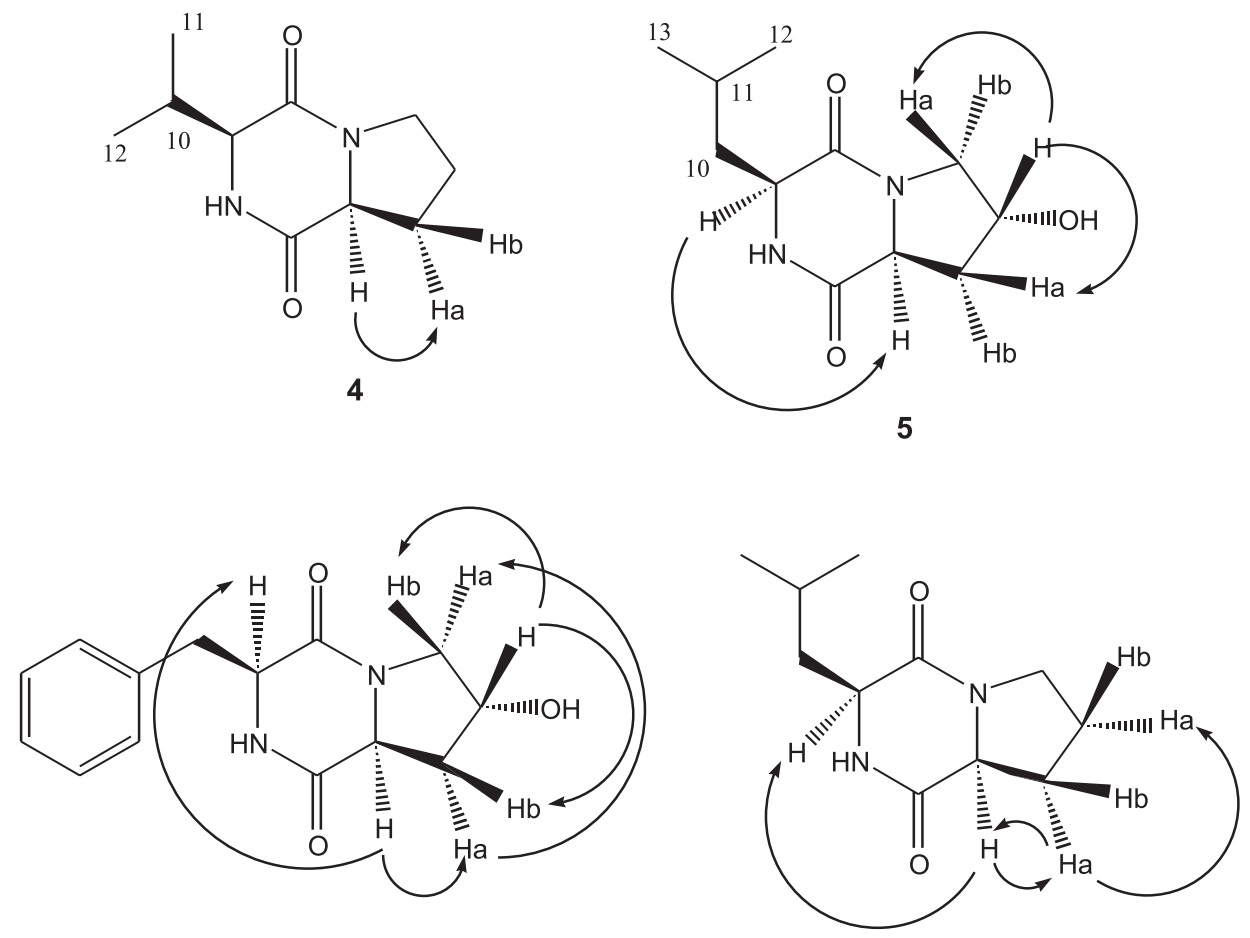

6 7

Figure 1. Structures and NOESY correlations of the isolated compounds. Cyclo (L)-Pro-(L)-Phe (1), cyclo (L)-Pro-Gly (2), cyclo (L)-Pro-(L)Pro (3), cyclo (L)-Pro-(L)-Val (4), cyclo (L)-4-OH-Pro-(L)-Leu (5), cyclo (L)-4-OH-Pro-(L)-Phe (6), and cyclo (L)-Pro-(L)-Leu (7). 
concentration of $10^{3}$ colony forming units $\left(\mathrm{CFU} \mathrm{mL} \mathrm{mL}^{-1}\right)$. Penicillin G (Sigma) was used as positive control and the negative control was run for a solution of DMSO and tryptone soya broth. Also, it was included both inoculated wells, which controls the adequacy of the broth to support the growth of the organisms, and uninoculated wells, which was free of antimicrobial agent to verify the sterility of the medium. The microplates (96-well) were incubated at $37^{\circ} \mathrm{C}$ for 24 hours. After that, $40 \mu \mathrm{L}$ of 2,3,5- triphenyltetrazolium chloride $(0.7 \%)$ in aqueous solution were added to indicate the viability of microorganisms. ${ }^{17}$

\section{Results and Discussion}

The crude chloroform extract from A. fumigatus culture broth exhibited activity against Micrococcus luteus and Staphylococcus aureus, providing inhibition zones of 21 $\mathrm{mm} \pm 0.577$ and $25 \mathrm{~mm} \pm 0.577$, respectively, by using the agar diffusion method. The results of bioautography analysis displayed two large overlapping inhibition zones, at Rf values of 0.34 and 0.52 .

The chromatographic purification of chloroform extract, by using a combination of Si gel flash chromatography and high-performance liquid chromatography, furnished 7 diketopiperazines (Figure 1).

The identification of diketopiperazines 1-7 was straightforward based on the presence of both the characteristic ${ }^{13} \mathrm{C}$ NMR chemical shifts for the amide carbonyl groups ( $\delta$ 167-172) and the ${ }^{1} \mathrm{H}$ NMR signals of the amino acids. The presence of proline moiety as one of the components of 1-4 and $\mathbf{7}$ was deduced by the presence of methylene multiplets in the spectra $(\delta 1.15$ $-3.59,6 \mathrm{H})$ and by $\mathrm{H}-\mathrm{C}$ correlations observed in the
HMBC experiments. Analysis of HMBC experiment showed the correlation of C-1 and C- 6 with $\mathrm{H}-3$ for compounds 1, 3, 6 and 7. Compounds 5 and $\mathbf{6}$ bear a hydroxyproline moiety $\left[\delta_{\mathrm{H}} 4.45(\mathrm{H}-4), \delta_{\mathrm{C}} 69.0(\mathrm{C}-4)\right.$ and $\delta_{\mathrm{H}} 4.27(\mathrm{H}-4), \delta_{\mathrm{C}} 68.9(\mathrm{C}-4)$, respectively] instead of a proline one. Analysis of the NMR spectra indicated that phenylalanine, glycine, valine and leucine were the other amino acid moieties present in compounds 1-7 (Table 1, 2 and 3).

Diketopiperazine $\mathbf{1}$ bears the molecular formula $\mathrm{C}_{14} \mathrm{H}_{16} \mathrm{~N}_{2} \mathrm{O}_{2}$, which was established by mass spectrometry, using electrospray ionization (ESI). The molecular weight of compound 1 was deduced as 244 by the quasimolecular ions at $m / z 245[\mathrm{M}+\mathrm{H}]^{+}, 267[\mathrm{M}+\mathrm{Na}]^{+}$and $283[\mathrm{M}+\mathrm{K}]^{+}$. The molecular formula of diketopiperazine $\mathbf{6}$ was assigned as $\mathrm{C}_{14} \mathrm{H}_{16} \mathrm{~N}_{2} \mathrm{O}_{3}$, which contains one additional oxygen in relation to compound $\mathbf{1}$. These data were well consistent

Table 1. ${ }^{1} \mathrm{H}$ NMR (400 MHz, $\mathrm{CD}_{3} \mathrm{OD}, \delta$ values) data of $\mathbf{1}$ and $\mathbf{6}$

\begin{tabular}{|c|c|c|}
\hline $\mathrm{H}$ & 1 & 6 \\
\hline 1 & - & - \\
\hline 2 & - & - \\
\hline \multirow[t]{2}{*}{3} & $3 \mathrm{a}: 3.48-3.56 \mathrm{~m}(1 \mathrm{H})$ & 3a: $3.26 \mathrm{~d}(13.1 \mathrm{~Hz} ; 1 \mathrm{H})$ \\
\hline & $3 b: 3.33-3.39 \mathrm{~m}(1 \mathrm{H})$ & 3b: $3.70 \mathrm{dd}(5.0 ; 13.1 \mathrm{~Hz} ; 1 \mathrm{H})$ \\
\hline 4 & $1.75-1.83 \mathrm{~m}(2 \mathrm{H})$ & $4.27 \mathrm{br} \mathrm{t}(5.0 \mathrm{~Hz} ; 1 \mathrm{H})$ \\
\hline \multirow[t]{2}{*}{5} & 5a: $1.15-1.24 \mathrm{~m}(1 \mathrm{H})$ & 5a: 2.06 ddd $(1.0 ; 5.8 ; 13.0 \mathrm{~Hz} ; 1 \mathrm{H})$ \\
\hline & $5 \mathrm{~b}: 2.04-2.12 \mathrm{~m}(1 \mathrm{H})$ & $5 \mathrm{~b}: 1.37 \mathrm{ddd}(5.0 ; 11.8 ; 13.0 \mathrm{~Hz} ; 1 \mathrm{H})$ \\
\hline 6 & 4.06 ddd $(1.7 ; 6.3 ; 10.8 \mathrm{~Hz} ; 1 \mathrm{H})$ & 4.36 ddd $(1.8 ; 5.8 ; 11.8 \mathrm{~Hz} ; 1 \mathrm{H})$ \\
\hline 7 & - & - \\
\hline 8 & 4.56 br s $(1 \mathrm{H})$ & 4.56 br s $(1 \mathrm{H})$ \\
\hline 9 & 4.44 ddd $(1.0 ; 4.8 ; 5.0 \mathrm{~Hz} ; 1 \mathrm{H})$ & 4.48 ddd $(2.0 ; 4.8 ; 5.3 \mathrm{~Hz} ; 1 \mathrm{H})$ \\
\hline \multirow[t]{2}{*}{10} & 10a: 3.14 dd $(5.0 ; 14.4 \mathrm{~Hz} ; 1 \mathrm{H})$ & 10a: $3.14 \mathrm{dd}(5.3 ; 14.2 \mathrm{~Hz} ; 1 \mathrm{H})$ \\
\hline & 10b: $3.18 \mathrm{dd}(4.8 ; 14.4 \mathrm{~Hz} ; 1 \mathrm{H})$ & 10b: $3.18 \mathrm{dd}(4.8 ; 14.2 \mathrm{~Hz} ; 1 \mathrm{H})$ \\
\hline 1 ' & - & - \\
\hline 2 ' & $7.20-7.29 \mathrm{~m}(1 \mathrm{H})$ & $7.20-7.29 \mathrm{~m}(1 \mathrm{H})$ \\
\hline 3 ' & $7.20-7.29 \mathrm{~m}(1 \mathrm{H})$ & $7.20-7.29 \mathrm{~m}(1 \mathrm{H})$ \\
\hline 4 & $7.20-7.29 \mathrm{~m}(1 \mathrm{H})$ & $7.20-7.29 \mathrm{~m}(1 \mathrm{H})$ \\
\hline
\end{tabular}

Table 2. ${ }^{1} \mathrm{H}$ NMR (400 MHz, $\mathrm{CD}_{3} \mathrm{OD}, \delta$ values) data of $\mathbf{2 , 3}, \mathbf{4}, \mathbf{5}$ and 7

\begin{tabular}{|c|c|c|c|c|c|}
\hline $\mathrm{H}$ & 2 & 3 & 4 & 5 & 7 \\
\hline 1 & - & - & - & - & - \\
\hline 2 & - & - & - & - & - \\
\hline \multirow[t]{2}{*}{3} & $3.44-3.56 \mathrm{~m}(2 \mathrm{H})$ & $3.44-3.54 \mathrm{~m}(4 \mathrm{H})$ & $3.45-3.59 \mathrm{~m}(2 \mathrm{H})$ & 3a: $3.65 \mathrm{dd}(4.2 ; 12.6 \mathrm{~Hz} ; 1 \mathrm{H})$ & $3.47-3.51 \mathrm{~m}(2 \mathrm{H})$ \\
\hline & & & & $3 \mathrm{~b}: 3.43 \mathrm{dd}(0.5 ; 12.6 \mathrm{~Hz} ; 1 \mathrm{H})$ & \\
\hline \multirow[t]{2}{*}{4} & $1.84-2.01 \mathrm{~m}(2 \mathrm{H})$ & $1.92-2.09 \mathrm{~m}(4 \mathrm{H})$ & $1.84-2.01 \mathrm{~m}(2 \mathrm{H})$ & $4.45 \mathrm{brt}(4.2 \mathrm{~Hz} ; 1 \mathrm{H})$ & 4a: $1.96-2.05 \mathrm{~m}(1 \mathrm{H})$ \\
\hline & & & & & 4b: $1.81-1.94 \mathrm{~m}(1 \mathrm{H})$ \\
\hline \multirow[t]{2}{*}{5} & $5 \mathrm{a}: 2.23-2.31 \mathrm{~m}(1 \mathrm{H})$ & $5 \mathrm{a}: 2.23-2.33 \mathrm{~m}(2 \mathrm{H})$ & $5 \mathrm{a}: 2.28-2.34 \mathrm{~m}(1 \mathrm{H})$ & 5a: 2.27 ddd $(1.0 ; 6.5 ; 13.1 \mathrm{~Hz} ; 1 \mathrm{H})$ & 5a: $2.24-2.34 \mathrm{~m}(1 \mathrm{H})$ \\
\hline & $5 b: 1.84-2.01 \mathrm{~m} \mathrm{(1H)}$ & $5 b: 1.92-2.09 \mathrm{~m} \mathrm{(2H)}$ & $5 b: 1.84-2.01 \mathrm{~m}(1 \mathrm{H})$ & 5b: 2.07 ddd $(4.2 ; 11.1 ; 13.1 \mathrm{~Hz} ; 1 \mathrm{H})$ & $5 \mathrm{~b}: 1.96-2.05 \mathrm{~m}(1 \mathrm{H})$ \\
\hline 6 & 4.21 ddd $(1.7 ; 6.8 ; 11.1 \mathrm{~Hz} ; 1 \mathrm{H})$ & $4.31-4.36 \mathrm{~m}(1 \mathrm{H})$ & $4.21 \mathrm{ddd}(2.2 ; 6.5 ; 12.1 \mathrm{~Hz} ; 1 \mathrm{H})$ & $4.51 \mathrm{ddd}(1.2 ; 6.5 ; 11.1 \mathrm{~Hz} ; 1 \mathrm{H})$ & 4.25 ddd $(1.7 ; 6.3 ; 11.1 \mathrm{~Hz} ; 1 \mathrm{H})$ \\
\hline 7 & - & - & - & - & - \\
\hline 8 & $4.56 \mathrm{br} \mathrm{s}(1 \mathrm{H})$ & - & $4.56 \mathrm{br} \mathrm{s}(1 \mathrm{H})$ & 4.56 br s $(1 \mathrm{H})$ & $4.56 \mathrm{br} \mathrm{s}(1 \mathrm{H})$ \\
\hline \multirow[t]{2}{*}{9} & 9a: $4.06 \mathrm{dd}(2.0 ; 16.9 \mathrm{~Hz} ; 1 \mathrm{H})$ & $4.31-4.36 \mathrm{~m}(1 \mathrm{H})$ & $4.01-4.03 \mathrm{~m}(1 \mathrm{H})$ & $4.13-4.18 \mathrm{~m}(1 \mathrm{H})$ & $4.09-4.15 \mathrm{~m}(1 \mathrm{H})$ \\
\hline & 9b: $3.69 \mathrm{~d}(16.9 \mathrm{~Hz} ; 1 \mathrm{H})$ & & & & \\
\hline \multirow[t]{2}{*}{10} & - & - & 2.48 dsept $(2.5 ; 6.9 \mathrm{~Hz} ; 1 \mathrm{H})$ & 10a: $1.83-1.94 \mathrm{~m} \mathrm{(1H)}$ & 10a: $1.81-1.94 \mathrm{~m}(1 \mathrm{H})$ \\
\hline & & & & $10 \mathrm{~b}: 1.46-1.53 \mathrm{~m} \mathrm{(1H)}$ & $10 \mathrm{~b}: 1.47-1.56 \mathrm{~m} \mathrm{(1H)}$ \\
\hline 11 & - & - & $0.93 \mathrm{~d}(6.9 \mathrm{~Hz} ; 3 \mathrm{H})$ & $1.83-1.94 \mathrm{~m}(1 \mathrm{H})$ & $1.81-1.94 \mathrm{~m}(1 \mathrm{H})$ \\
\hline 12 & - & - & $1.07 \mathrm{~d}(6.9 \mathrm{~Hz} ; 3 \mathrm{H})$ & $0.95 \mathrm{~d}(6.5 \mathrm{~Hz} ; 3 \mathrm{H})$ & $0.94 \mathrm{~d}(6.5 \mathrm{~Hz} ; 3 \mathrm{H})$ \\
\hline 13 & - & - & - & $0.96 \mathrm{~d}(6.5 \mathrm{~Hz} ; 3 \mathrm{H})$ & $0.95 \mathrm{~d}(6.5 \mathrm{~Hz} ; 3 \mathrm{H})$ \\
\hline
\end{tabular}


Table 3. ${ }^{13} \mathrm{C}$ NMR (100 MHz, $\mathrm{CD}_{3} \mathrm{OD}, \delta$ values) data of compounds 1-7.

\begin{tabular}{cccccccc}
\hline C & $\mathbf{1}$ & $\mathbf{2}$ & $\mathbf{3}$ & $\mathbf{4}$ & $\mathbf{5}$ & $\mathbf{6}$ & $\mathbf{7}$ \\
\hline 1 & 167.3 & 165.3 & 168.6 & 167.8 & 167.8 & 167.4 & 168.5 \\
2 & - & - & - & - & - & - & - \\
3 & 45.9 & 45.1 & 45.8 & 46.1 & 56.0 & 55.6 & 46.0 \\
4 & 23.1 & 22.1 & 23.2 & 23.2 & 69.0 & 68.9 & 23.2 \\
5 & 29.7 & 28.2 & 28.8 & 29.4 & 37.0 & 39.2 & 28.8 \\
6 & 60.4 & 58.6 & 61.7 & 60.1 & 58.0 & 58.0 & 60.1 \\
7 & 171.3 & 170.8 & 168.6 & 172.6 & 171.9 & 171.6 & 172.6 \\
8 & - & - & - & - & - & - & - \\
9 & 58.0 & 45.8 & 61.7 & 61.3 & 54.0 & 57.0 & 54.0 \\
10 & 38.6 & - & - & 30.1 & 38.0 & 38.4 & 38.2 \\
11 & - & - & - & 16.3 & 25.0 & - & 25.0 \\
12 & - & - & - & 18.3 & 21.0 & - & 21.4 \\
13 & - & - & - & - & 22.1 & - & 22.8 \\
1 & 137.6 & - & - & - & - & 137.8 & - \\
2 & 131.4 & - & - & - & - & 131.3 & - \\
3, & 130.1 & - & - & - & - & 130.0 & - \\
4 & 128.5 & - & - & - & - & 128.9 & - \\
\hline
\end{tabular}

with theirs ${ }^{1} \mathrm{H}$ and ${ }^{13} \mathrm{C}$ NMR data. The ${ }^{1} \mathrm{H}$ NMR spectra of $\mathbf{1}$ and 6 displayed signals of methylene benzylic protons groups (H-10) attached to monosubstituted benzene rings $(\delta$ 3.14- 3.18). These data suggested a phenylalanine moiety for these compounds.

The ${ }^{1} \mathrm{H}$ spectrum of the compound $\mathbf{2}$ showed the signals at $\delta 4.06(J 2.0$ and $16.9 \mathrm{~Hz}$, dd, 1H, H-9a) and $\delta 3.69(J$ $16.9 \mathrm{~Hz}, \mathrm{~d}, 1 \mathrm{H}, \mathrm{H}-9 \mathrm{~b})$, both protons are attached to a carbon at $\delta 45.8$, as observed in HMQC experiment, indicating a glycine moiety for this compound.

The ${ }^{1} \mathrm{H}$ spectrum of the compound $\mathbf{4}$ displayed two doublets at $\delta 0.93(J 6.9 \mathrm{~Hz}, 3 \mathrm{H}, \mathrm{H}-11)$ and $\delta 1.07(J 6.9$ $\mathrm{Hz}, 3 \mathrm{H}, \mathrm{H}-12)$ indicating the presence of two methyl groups. Moreover, the signals at $\delta 2.48(J 2.5$ and $6.9 \mathrm{~Hz}$, dsept, $1 \mathrm{H}, \mathrm{H}-10)$ and $\delta 4.01-4.03(\mathrm{~m}, 1 \mathrm{H}, \mathrm{H}-9)$ allowed to propose a valine moiety for this compound.

The molecular formula of diketopiperazine $\mathbf{5}$ contains one additional oxygen in relation to compound 7. Their ${ }^{1} \mathrm{H}$ and ${ }^{13} \mathrm{C}$ NMR signals showed close correspondence, except for the signals of both hydroxyproline and proline residues, respectively. Their ${ }^{1} \mathrm{H}$ spectra showed two doublets at $\delta 0.95(J 6.5 \mathrm{~Hz}, 3 \mathrm{H}, \mathrm{H}-12)$ and $\delta 0.94(J 6.5$ $\mathrm{Hz}, 3 \mathrm{H}, \mathrm{H}-12)$ for $\mathbf{5}$ and $\mathbf{7}$, respectively, as well as other two doublets at $\delta 0.96(J 6.5 \mathrm{~Hz}, 3 \mathrm{H}, \mathrm{H}-13)$ and $\delta 0.95(J 6.5$ $\mathrm{Hz}, 3 \mathrm{H}, \mathrm{H}-13)$, indicating the presence of two methyl groups attached to the molecules. In addition, the signals at $\delta$ 4.13- 4.18 (m, 1H, H-9), $\delta 1.83-1.94$ (m, 1H, H-10a), $\delta$ 1.46- $1.53(\mathrm{~m}, 1 \mathrm{H}, \mathrm{H}-10 \mathrm{~b})$ and $\delta 1.83-1.94(\mathrm{~m}, 1 \mathrm{H}, \mathrm{H}-11)$ of compound 5 and the signals at $\delta 4.09-4.15(\mathrm{~m}, 1 \mathrm{H}, \mathrm{H}-$ 9), $\delta 1.81-1.94(\mathrm{~m}, 1 \mathrm{H}, \mathrm{H}-10 \mathrm{a}), \delta 1.47-1.56(\mathrm{~m}, 1 \mathrm{H}, \mathrm{H}-10 \mathrm{~b})$ and $\delta 1.81-1.94(\mathrm{~m}, 1 \mathrm{H}, \mathrm{H}-11)$ for compound 7 allowed to propose a leucine moiety for these compounds.

The spectra data for all compounds showed signals due to one $\mathrm{N}-\mathrm{H}$ proton $(\delta 4.56$, br s, $1 \mathrm{H})$, with exception of diketopiperazine 3. The EIMS data showed peaks at $\mathrm{m} / \mathrm{z}$ $195[\mathrm{M}+\mathrm{H}]^{+}, 217[\mathrm{M}+\mathrm{Na}]^{+}$and $233[\mathrm{M}+\mathrm{K}]^{+}$, which allowed to propose the structure of cyclo Pro-Pro for compound $\mathbf{3}$.

${ }^{1} \mathrm{H}$ and ${ }^{13} \mathrm{C}$ NMR previously reported data for the compounds 1, 4, 5, 6 and $\mathbf{7}$ are in agreement with obtained data for isolated diketopiperazines. ${ }^{18-20}$

Regarding the absolute stereochemistries of the diketopiperazines, it was possible to determine that all diketopiperazines were biosynthesized from $\mathrm{L}$-amino acids (Table 4). All the derivatized obtained from the hydrolysis of the diketopiperazines displayed the same retention times of the derivatized standard L-amino acids. The modified Marfey's method was successfully applied to the determination of the absolute configuration of amino acids. It was done by using a linear gradient starting with the mixture of triethylamine phosphate buffer (50 mmol L-1 $\mathrm{pH} 3.5) /$ $\mathrm{MeCN}$ (9:1) and finishing with triethylamine phosphate buffer ( $\left.50 \mathrm{mmol} \mathrm{L}^{-1}, \mathrm{pH} 3.5\right) / \mathrm{MeCN}(6: 4)$, over 45 minutes, (flow rate $1.0 \mathrm{~mL} \mathrm{~min}^{-1}$ ). The original method describes a linear gradient starting with the mixture of triethylammonium phosphate buffer $\left(50 \mathrm{mmol} \mathrm{L}^{-1}, \mathrm{pH} 3.0\right) / \mathrm{MeCN}$ (9:1) and finishing with triethylammonium phosphate buffer $\left(50 \mathrm{mmol} \mathrm{L}^{-1}, \mathrm{pH} 3.0\right) / \mathrm{MeCN}(1: 1)$, over 60 minutes (flow rate $2.0 \mathrm{~mL} \mathrm{~min}^{-1}$ ). ${ }^{14}$

Table 4. HPLC reversed-phase retention times of the L-amino acid standard derivatives

\begin{tabular}{ll}
\hline Amino acid derivative & Retention time / min \\
\hline 4-OH-Proline & 14.9 \\
Glycine & 24.1 \\
Proline & 26.1 \\
Valine & 32.7 \\
Phenylalanine & 39.3 \\
Leucine & 39.4 \\
FDAA & 31.5 \\
\hline
\end{tabular}

Diketopiperazines corresponding to cyclic dipeptides have been isolated from microorganisms, sponges and from a variety of tissues and body fluids. ${ }^{18,21,22}$ These heterocyclic compounds display several biological properties, such as: antimicrobial, antitumor, antiviral and plant growth regulation. ${ }^{19,23}$ Fdhila et al. ${ }^{20}$ reported the isolation of DDdiketopiperazines cyclo (D)-Pro-(D)-Phe, (D)-Pro-(D)-Leu, (D)-Pro-(D)-Val and (D)-4-OH-Pro-(D)-Phe from marine bacteria associated with cultures of Pecten maximus. These DD-diketopiperazines presented a potent inhibitory activity against the pathogen Vibrio anguillarum, while the LL-enantiomers were completely inactive. ${ }^{20}$ Therefore, the D-stereochemistry seems to be important for the biological activity. 
All the isolated compounds inhibited the growth of Staphylococcus aureus and Micrococcus luteus only at the concentration of $2.9 \mathrm{mmol} \mathrm{L}^{-1}$. This result is insignificant in comparison with penicillin, for which the MIC values were established at $0.25 \eta \mathrm{mol} \mathrm{L}^{-1}$ and 0.12 $\eta \mathrm{mol} \mathrm{L}^{-1}$, respectively. It is important to point out that the literature reports ${ }^{24}$ the antimicrobial activity of the cycle (L)-Pro-(L)-Phe against a clinical isolated strain of Staphylococcus aureus at the concentration of $15 \eta \mathrm{mol}$ $\mathrm{L}^{-1}$ but, in the protocol used in this study, no activity was detected by using the mentioned concentration.

The origin of diketopiperazines has been questioned, once several cyclic dipeptides have been found in fermentation broths and cultures of yeast, as well as in lichens and fungi. ${ }^{25}$ It is known that diketopiperazines can be generated via non-enzymatic cyclization of linear dipeptides at extremes of temperature. ${ }^{26}$ It was checked whether diketopiperazines would have been generated by heat sterilization and incubation of the medium culture during the fermentation process. However, these cyclic dipeptides were not detected in the HPLC profiles of the obtained extracts from the culture medium without the fungus.

To our knowledge, these cyclic dipeptides have not been previously reported for A. fumigatus, with exception of the cyclo (L)-Pro-(L)-Leu. ${ }^{27}$

\section{Acknowledgments}

We are grateful to "Fundação de Amparo à Pesquisa do Estado de São Paulo (FAPESP)" Brazil for financial support (proc. 99/09850-8), to Dr. Suraia Said for providing the strain of A. fumigatus, to Dr. Norberto P. Lopes for the obtainment of MS data, as well as to Dr. Roberto G. S. Berlinck for providing the FDAA reagent and the authentic L-amino acids standards.

\section{References}

1. Baker, D. D.; Alvi, K. A.; Curr. Opin. Biotechnol. 2004, 15, 576.

2. Czarnick, A. W.; Acc. Chem. Res. 1996, 29, 112.

3. Donadio, S.; Monciardini, P.; Alduina, R.; Mazza, P.; Chiocchini, C.; Cavaleti, L.; Sosio, M.; Puglia, A.M.; J. Biotechnol. 2002, 99, 187.

4. Son, K.H.; Kim, Y. K.; Lee, H. W.; Lee, W. S.; Kim, S. U.; Jeong, T. S.; Kwon, B. M.; Bok, S. H.; Biotechnol. Lett. 1996, $18,1297$.
5. Symoens, F.; Bertout, S.; Piens, M. A.; Burnod, J.; Renaud,F.; Nolard, N.; Chapuis, F.; Grillot, R.; EBGA Network.; J. Heart Lung Transplant. 2000, 20, 970.

6. Debeaupuis, J. P.; Sarfati, J.; Chazalet, V.; Latgé, J. P.; Infect. Immun. 1997, 65, 3080.

7. Varga, J.; Tóth, B.; Infect. Genet. Evol. 2003, 3, 3.

8. Knight, V.; Sanglier, J. J.; DiTullio, D.; Braccili, S.; Bonner, P.; Waters, J.; Hughes, D.; Zhang, L.; Appl. Microbiol. Biotechnol. 2003, 62, 446.

9. Schulz, B.; Boyle, C.; Draeger, S.; Rommert, A. K.; Krohn, K.; Mycol. Res. 2002, 106, 996.

10. Mukhopadhyay, T.; Roy, K.; Coutinho, L.; Rupp, R. H.; Ganguli, B. N.; J. Antibiot. 1987, 40, 1050.

11. Ando, O.; Satake, H.; Nakajima, M.; Sato, A.; Nakamura, T.; Kinoshita, T.; Furuya, K.; Haneishi, T.; J. Antibiot. 1991, 44, 382.

12. Jackson, M.; Karwoswski, J. P.; Humphrey, P. E.; Kohl, W. L.; Barlow, G. J.; Tanaka, S. K.; J. Antibiot. 1993, 46, 34.

13. Still, C. S.; Kahn, M.; Mitra, A.; J. Org. Chem. 1978, 43, 2923.

14. Marfey, P.; Ottesen, M.; Carlsberg Res. Commun. 1984, 49, 585.

15. Hamburger, M. O.; Cordell, G. A.; J. Nat. Prod. 1987, 50, 19.

16. Andrews, J. M.; J. Antimicrob. Chemother. 2001, $48,5$.

17. Leverone, M.R.; Owen, T.C.; Tieder, F.S.; Stewart, G.J.; Lim, D.U.; J. Microbiol. Methods 1996, 25, 49.

18. Ström, K.; Sjögren, J.; Broberg, A.; Schnürer, J.; Appl. Environ. Microbiol. 2002, 68, 4322.

19. Ienaga, K.; Nakamura, K.; Goto, T.; Tetrahedron Lett. 1987, 28, 1285 .

20. Fdhila, F.; Vázquez, V.; Sánchez, J. L.; Riguera, R.; J. Nat. Prod. 2003, 66, 1299.

21. De Rosa, S.; Mitova, M.; Tommonaro, G.; Biomol. Eng. 2003, $20,311$.

22. Rudi, A.; Kashman, Y.; J. Nat. Prod. 1994, 57, 829.

23. Rhee, K. H.; Int. J. Antimicrob. Agents 2004, 24, 423.

24. Graz, M.; Hunt, A.; Jamie, H.; Grant, G.; Milne, P.; Pharmazie 1999, 54, 772 .

25. Prasad, C.; Peptides 1995, 16, 151.

26. Holden, M. T. G.; Chhabra, S. R.; de Nys, R.; Stead, P.; Bainton, N. J.; Hill, P. J.; Manefield, M.; Kumar, N.; Labatte, M.; England, D.; Rice, S.; Givskov, M.; Salmond, G. P. C.; Stewart, G. S. A. B.; Bycroft, B. W.; Kjelleberg, S. A.; Williams, P.; Mol. Microbiol. 1999, 33, 1254.

27. Hanson, F. R.; Eble, T. E.; J. Bacteriol. 1949, 58, 527.

Received: April 20, 2005

Published on the web: October 11, 2005

FAPESP helped in meeting the publication costs of this article. 